J. Clin. Chem. Clin. Biochem.

Vol. 17, 1979, pp. 205-210

\title{
Age Related Reference Values for Urinary Free Amino Acids: A Simple Method of Evaluation
}

\author{
By Ph. Parvy, Y. Huang and P. Kamoun \\ Laboratoire de Biochimie Génétique Hôpital Necker, Paris, France
}

(Received May 11/October 23, 1978)

Summary: The urinary excretion of free amino acids has been studied on 339 normal subjects, using ion exchange chromatography. Age related reference values were obtained. A simple method for their evaluation is discussed, and the application of the method to the detection of increased glycinuria, resulting from $n$-dipropyl acetate therapy, is described.

\section{Altersbezogene Referenzwerte für freie Aminosäuren im Harn: Eine einfache Methode für ihre Bewertung}

Zusammenfassung: Die Ausscheidung freier Aminosäuren im Harn wurde bei 339 normalen Probanden mit Hilfe der Ionenaustauschchromatographie untersucht. Altersbezogene Referenzwerte wurden erhalten. Eine einfache Methode für ihre Bewertung und deren Anwendung zum Nachweis einer erhöhten Glycinurie bei Therapie mit $n$-Dipropylacetat wird diskutiert.

\section{Introduction}

Aminoaciduria has been the subject of numerous reports, but there are relatively few reference values for normal subjects, obtained by column chromatography $(1,2)$. The present work describes a simple procedure for the determination of these values.

\section{Materials and Methods}

Subjects studied were hospitalized children and adults. Patients with enzymatic defects and premature infants (3), and patients with renal failure or with other diseases for which variations of aminoaciduria have been described: muscular (4), bone (5), skin $(6,7)$ and eye $(8)$ diseases, were all excluded from the study. We also omitted patients whose therapy is known to induce either methodological interferences in amino acid chromatöğtraphy (9) or aminoaciduria variations (10-15). All subjects studied (191 males and 148 females) were in good nutritional state and their protein intake was normal. Physical activity was judged to be about the same for all subjects. Aminoaciduria was also studied on one subject during 5 days, and on 10 subjects receiving $n$-dipropyl acetate therapy.

The single morning urine sample was collected in a bottle containing a thymol crystal. The samples were either immediatly prepared for analysis or kept at $-24^{\circ} \mathrm{C}$. This storage does not significantly modify aminoaciduria meàsurements (16). Creatinine was assayed by the Jaffe's reaction (17). $50 \mathrm{mg}$ of crystallized sulfosalicylic acid were added to $1 \mathrm{ml}$ of urine and the sample was then centrifuged $10 \mathrm{~min}$ at $500 \mathrm{~g}$. A part of the supernatant (corresponding to $50 \mu \mathrm{g}$ of creatinine) was used for the chromatography, and norleucine (62.5 nmoles) was added as internal standard. The column chromatography was performed on a Technicon TSM Amino Acid Analyzer. The total analysis employed only one column (18) length $35 \mathrm{~cm}$, internal diameter $0.63 \mathrm{~cm}$ with chromobeads Type $C 3$ resin. The column was eluted by a discontinuous gradient (19) of $0.1 \mathrm{~mol} / 1$ citric acid - sodium citrate buffers: for 70 min with pH 3.25 buffer containing per liter $60 \mathrm{ml}$ of methycellosolve and $5 \mathrm{ml}$ of thiodiethanol; then for $40 \mathrm{~min}$ with $\mathrm{pH} 4.25$ buffer; followed by $110 \mathrm{~min}$ with $\mathrm{pH} 6.0$ buffer containing $\mathrm{NaCl} 0.55 \mathrm{~mol} / \mathrm{l}$.

Elution was performed at $57.5^{\circ} \mathrm{C}$ with a $0.55 \mathrm{ml} / \mathrm{min}$ flow. This method separated: phospho-ethanolamine, taurine, hydroxyproline, aspartic acid, threonine, serine, glutamic acid + glutamine, citrulline, proline, glycine, alanine, cystine, valine, cystathionine, methionine, alloisoleucine, isoleucine, leucine, tyrosine, phenylalanine, hydroxylysine, histidine, lysine and arginine. When the $\mathrm{pH}$ of the buffer was shifted from 4.25 to 6.0 , homocystine, $\beta$-alanine, $\beta$-aminoisobutyric acid and $\boldsymbol{\gamma}$-aminoisobutyric acid were eluted together, after the peak of phenylalanine. Every tenth sample through the analyzer was a mixture of the 17 commonest amino acids and the internal standard ( $62.5 \mathrm{nmoles}$ of each). Only the fourteen aminoacids representing more of $90 \%$ of the whole aminoaciduria (1) were currently measured: threonine, serine, glutamic acid (+ glutamine), proline, glycine, alanine, cystine, valine, leucine, tyrosine, phenylalanine, histidine, lysine. The results were expressed either as $\mu \mathrm{mol} / \mathrm{g}$ creatinine or as a fraction of the sum of all 14 amino acids measured.

\section{Results}

Results obtained from the single morning urine samples of one subject are gathered in table 1 . The results expressed in $\mu \mathrm{mol} / \mathrm{g}$ creatinine show a relative stability, the largest variations being those of lysine, threonine, 
Tab. 1. Urinary excretion of free amino acids in one subject during 5 days in $\mu \mathrm{mol} / \mathrm{g}$ creatinine and as a fraction of the sum of amino acids (see Results).

\begin{tabular}{|c|c|c|c|c|c|c|c|}
\hline Day & 1 & 2 & 3 & 4 & 5 & Mean \pm S. D. & $\begin{array}{l}\text { Coeffi- } \\
\text { cients of } \\
\text { variation } \\
(\%)\end{array}$ \\
\hline $\begin{array}{l}\text { Threonine } \\
\text { ( } \mu \mathrm{mol} / \mathrm{g} \text { creatinine) } \\
\text { (fraction of the sum) }\end{array}$ & $\begin{array}{l}155 \\
0.062\end{array}$ & $\begin{array}{l}114 \\
0.056\end{array}$ & $\begin{array}{l}107 \\
0.058\end{array}$ & $\begin{array}{l}90 \\
0.049\end{array}$ & $\begin{array}{l}101 \\
0.052\end{array}$ & $\begin{aligned} 113.4 & \pm 28.7 \\
0: 055 & \pm 0.006\end{aligned}$ & $\begin{array}{l}25.3 \\
10.9\end{array}$ \\
\hline $\begin{array}{l}\text { Serine } \\
\text { ( } \mu \text { mol } / g \text { creatinine) } \\
\text { (fraction of the sum) }\end{array}$ & $\begin{array}{l}163 \\
0.066\end{array}$ & $\begin{array}{l}126 \\
0.061\end{array}$ & $\begin{array}{l}125 \\
0.067\end{array}$ & $\begin{array}{l}139 \\
0.075\end{array}$ & $\begin{array}{l}153 \\
0.078\end{array}$ & $\begin{aligned} 141.2 & \pm 19.3 \\
0.069 & \pm 0.008\end{aligned}$ & $\begin{array}{l}13.7 \\
11.6\end{array}$ \\
\hline $\begin{array}{l}\text { Glutamic acid + glutamine } \\
\text { (umol/g creatinine) } \\
\text { (fraction of the sum) }\end{array}$ & $\begin{array}{l}163 \\
0.066\end{array}$ & $\begin{array}{l}144 \\
0.071\end{array}$ & $\begin{array}{l}127 \\
0.068\end{array}$ & $\stackrel{168}{0.091}$ & $\begin{array}{l}180 \\
0.093\end{array}$ & $\begin{aligned} 156.4 & \pm 24.2 \\
0.078 & \pm 0.015\end{aligned}$ & $\begin{array}{l}15.5 \\
19.2\end{array}$ \\
\hline Proline & traces & traces & traces & traces & traces & & \\
\hline $\begin{array}{l}\text { Glycine } \\
\text { (umol/g creatinine) } \\
\text { (fraction of the sum) }\end{array}$ & $\begin{array}{l}535 \\
0.216\end{array}$ & $\begin{array}{l}466 \\
0.227\end{array}$ & $\begin{array}{l}418 \\
0.225\end{array}$ & $\begin{array}{l}417 \\
0.225\end{array}$ & $\stackrel{465}{0.239}$ & $\begin{aligned} 460.2 & \pm 55.7 \\
0.226 & \pm 0.009\end{aligned}$ & $\begin{array}{r}12.1 \\
4.0\end{array}$ \\
\hline $\begin{array}{l}\text { Alanine } \\
\quad \text { ( } \mathrm{mol} / \mathrm{g} \text { creatinine) } \\
\text { (fraction of the sum) }\end{array}$ & $\begin{array}{l}119 \\
0.048\end{array}$ & $\begin{array}{l}76 \\
0.037\end{array}$ & $\begin{array}{l}82 \\
0.044\end{array}$ & $\begin{array}{l}76 \\
0.041\end{array}$ & $\begin{array}{l}80 \\
0.041\end{array}$ & $\begin{aligned} 86.6 & \pm 21.1 \\
0.042 & \pm 0.005\end{aligned}$ & $\begin{array}{l}24.4 \\
11.9\end{array}$ \\
\hline $\begin{array}{l}1 / 2 \text { Cystine } \\
\text { (umol/g creatinine) } \\
\text { (fraction of the sum) }\end{array}$ & $\begin{array}{l}73 \\
0.029\end{array}$ & $\begin{array}{l}47 \\
0.023\end{array}$ & $\begin{array}{l}49 \\
0.026\end{array}$ & $\begin{array}{l}55 \\
0.029\end{array}$ & $\begin{array}{l}62 \\
0.032\end{array}$ & $\begin{aligned} 5 \overline{7} .2 & \pm 12.2 \\
0.028 & \pm 0.004\end{aligned}$ & $\begin{array}{l}21.3 \\
14.3\end{array}$ \\
\hline $\begin{array}{l}\text { Valine } \\
\text { (umol/g creatinine) } \\
\text { (fraction of the sum) }\end{array}$ & $\begin{array}{l}28 \\
0.011\end{array}$ & $\begin{array}{l}25 \\
0.012\end{array}$ & $\begin{array}{l}25 \\
0.013\end{array}$ & $\begin{array}{l}27 \\
0.015\end{array}$ & $\begin{array}{l}23 \\
0.012\end{array}$ & $\begin{aligned} 25.6 & \pm 2.3 \\
0.013 & \pm 0.001\end{aligned}$ & $\begin{array}{r}9.0 \\
13.1\end{array}$ \\
\hline $\begin{array}{l}\text { Leucine } \\
\text { ( } \mu \mathrm{mol} / \mathrm{g} \text { creatinine) } \\
\text { (fraction of the sum) }\end{array}$ & $\begin{array}{l}39 \\
0.016\end{array}$ & $\begin{array}{l}33 \\
0.016\end{array}$ & $\begin{array}{l}33 \\
0.018\end{array}$ & $\begin{array}{l}26 \\
0.014\end{array}$ & $\begin{array}{l}29 \\
0.015\end{array}$ & $\begin{array}{cl}32.0 & \pm 5.7 \\
0.016 & \pm 0.002\end{array}$ & $\begin{array}{l}17.0 \\
10.6\end{array}$ \\
\hline $\begin{array}{l}\text { Tyrosine } \\
\text { ( } \mu \text { mol/g creatinine) } \\
\text { (fraction of the sum) }\end{array}$ & $\begin{array}{l}107 \\
0.043\end{array}$ & $\begin{array}{l}100 \\
0.049\end{array}$ & $\begin{array}{l}86 \\
0.046\end{array}$ & $\begin{array}{l}98 \\
0.053\end{array}$ & $\begin{array}{l}78 \\
0.040\end{array}$ & $\begin{aligned} 93.8 & \pm 13.4 \\
0.046 & \pm 0.005\end{aligned}$ & $\begin{array}{l}14.3 \\
10.9\end{array}$ \\
\hline $\begin{array}{l}\text { Phenylalanine } \\
\text { (umol/g creatinine) } \\
\text { (fraction of the sum) }\end{array}$ & $\begin{array}{l}49 \\
0.020\end{array}$ & $\begin{array}{l}38 \\
0.019\end{array}$ & $\begin{array}{l}38 \\
0.020\end{array}$ & $\begin{array}{l}40 \\
0.021\end{array}$ & $\stackrel{34}{0.017}$ & $\begin{aligned} 39.8 & \pm 6.4 \\
0.019 & \pm 0.002\end{aligned}$ & $\begin{array}{r}16.1 \\
8 . \dot{9}\end{array}$ \\
\hline $\begin{array}{l}\text { Histidine } \\
\text { ( } \mu \text { mol/g creatinine) } \\
\text { (fraction of the sum) }\end{array}$ & $\begin{array}{l}654 \\
0.264\end{array}$ & $\begin{array}{l}542 \\
0.264\end{array}$ & $\begin{array}{l}480 \\
0.264\end{array}$ & $\begin{array}{l}493 \\
0.266\end{array}$ & $\begin{array}{l}500 \\
0.257\end{array}$ & $\begin{aligned} 533.8 & \pm 82.1 \\
0.263 & \pm 0.004\end{aligned}$ & $\begin{array}{r}15.4 \\
1.5\end{array}$ \\
\hline $\begin{array}{l}\text { Lysine } \\
\text { ( } 2 \mathrm{~mol} / \mathrm{g} \text { creatinine) } \\
\text { (fraction of the sum) }\end{array}$ & $\begin{array}{l}395 \\
0.159\end{array}$ & $\begin{array}{l}343 \\
0.167\end{array}$ & $\begin{array}{l}286 \\
0.154\end{array}$ & $\begin{array}{l}225 \\
0.121\end{array}$ & $\begin{array}{l}238 \\
0.122\end{array}$ & $\begin{aligned} 297.4 & \pm 82.7 \\
0.145 & \pm 0.025\end{aligned}$ & $\begin{array}{l}27.8 \\
17.2\end{array}$ \\
\hline
\end{tabular}

alanine and cystine. The coefficients of variation become smaller when the concentration of each amino acid is expressed as a fraction of the sum of the 14 amino acids measured (paired Student's test: $\mathrm{p}<0.01$ ).

The results expressed in $\mu \mathrm{mol} / \mathrm{g}$ creatinine for 339 subjects are shown in tables 2 and 3 . All subjects over 13 years old have been gathered in the same group. The aminoaciduria decreases with the increasing age of the subjects, especially for those amino acids that show the highest excretion. The large variance observed for each amino acid seems to be related to individual variations, both of aminoaciduria and of creatininuria. In table 4, each amino acid concentration is expressed as a fraction of the sum of currently measured amino acids. The variance observed is especially large in the first and second groups (less than 6 months of life). Significant increases of glutamic acid + glutamine $\left(\mathrm{p}<10^{-3}\right)$, tyrosine $\left(\mathrm{p}<10^{-7}\right)$, phenylalanine $\left(\mathrm{p}<10^{-9}\right)$, histidine $\left(\mathrm{p}<10^{-4}\right)$, valine $\left(\mathrm{p}<10^{-3}\right)$ and a significant decrease of glycinuria $\left(p<10^{-3}\right)$ are observed between the first and the second groups (table 3). In contrast, all fractions are almost constant over the age of 6 months, except for serine and lysine. The coefficients of variation observed in table 3 and 4 are compared by paired Student's test (table 5). For all amino acids except leucine, these coefficients are smaller when the results are expressed as a fraction of the sum of amino acids measured.

We had previously shown that glycinuria was increased by $n$-dipropyl acetate therapy $(12,15)$; this increase 


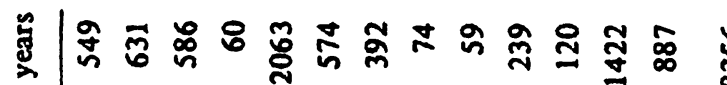
$\begin{array}{llllllllllllllll}m & 1 & 1 & 1 & 1 & 1 & 1 & 1 & 1 & 1 & 1 & 1 & 1 & 1 & 1\end{array}$

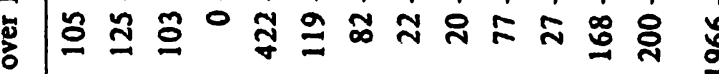

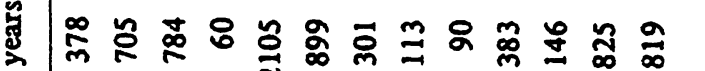
$\begin{array}{lllllllllllllll}\mathfrak{m} & 1 & 1 & 1 & 1 & 1 & 1 & 1 & 1 & 1 & 1 & 1 & 1 & 1 & 1\end{array}$

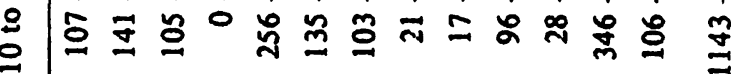

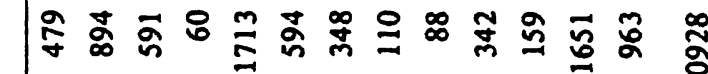
年

要

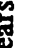

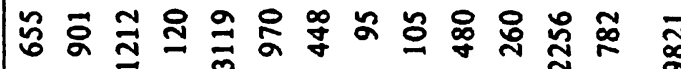

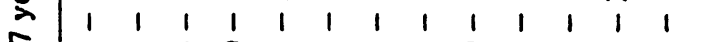

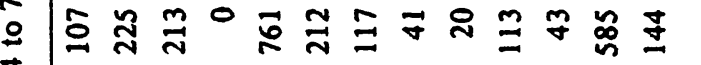

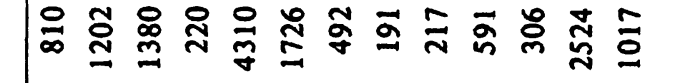
2 学隽

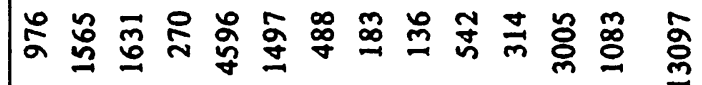

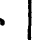

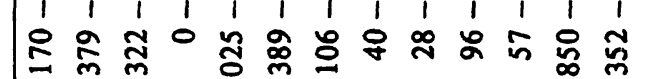
ذ)

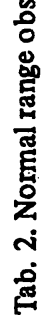

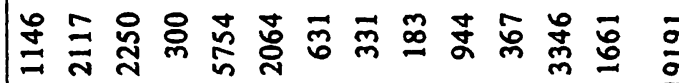
$\begin{array}{llllllllllllll}1 & 1 & 1 & 1 & 1 & 1 & 1 & 1 & 1 & 1 & 1 & 1 & 1 & 1\end{array}$

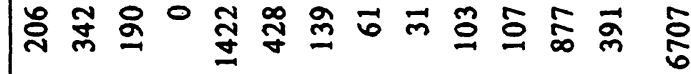

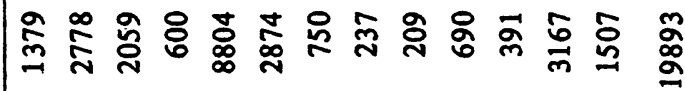
11111111111

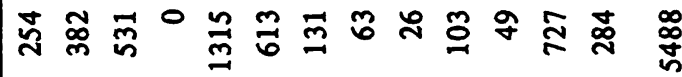

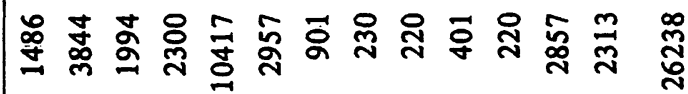

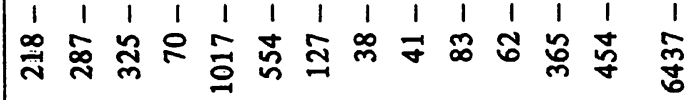

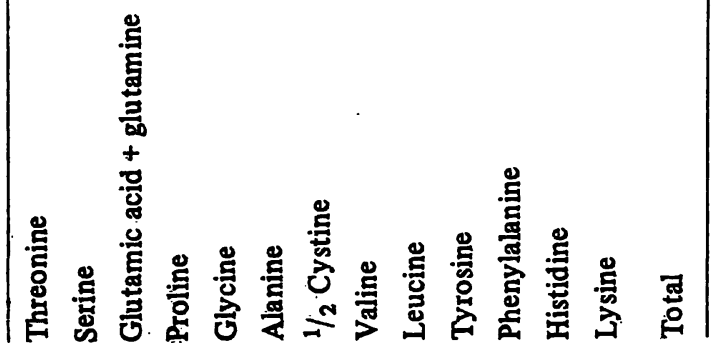

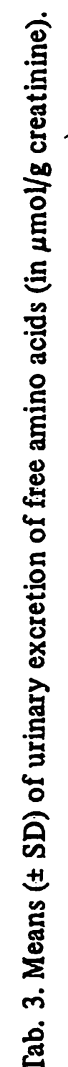

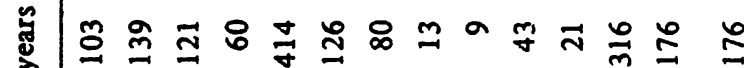
$m$ 药

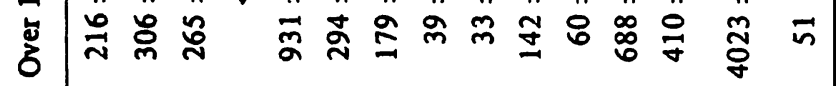
๓

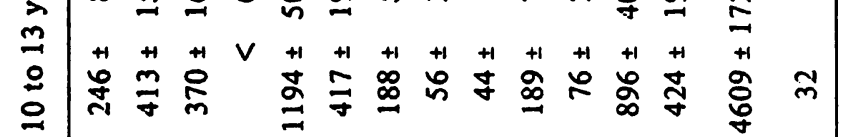

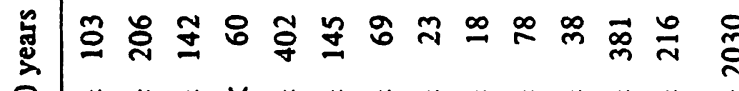

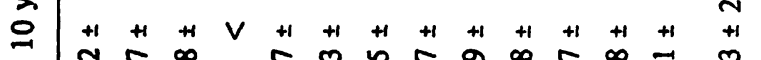

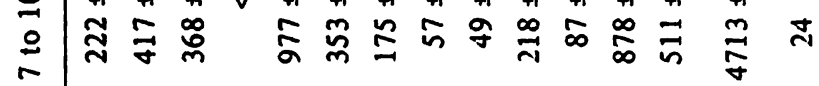

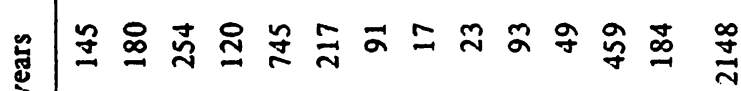
$\tilde{n}$

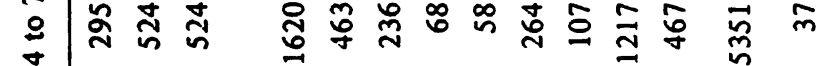

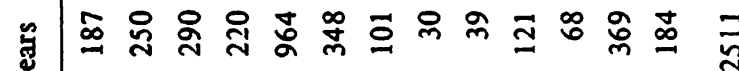

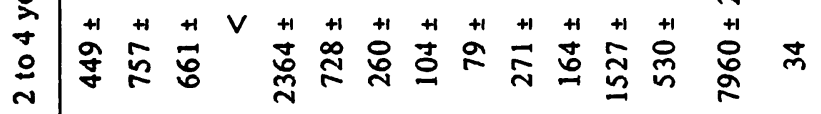

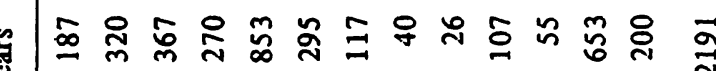

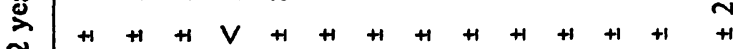

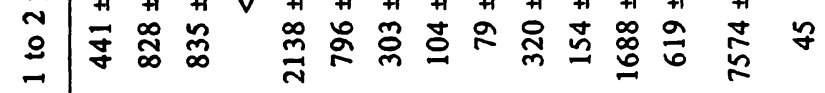

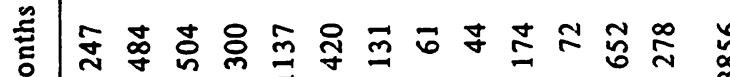
है

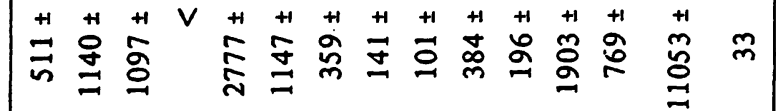

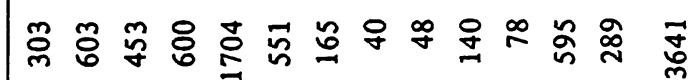

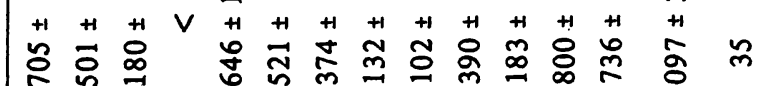

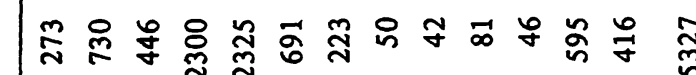
तथत

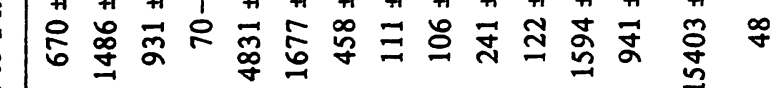

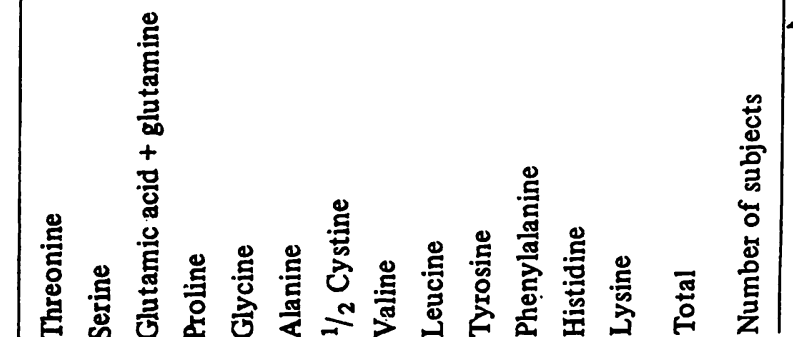


was subsequently found by others $(13,14)$. In 10 subjects the increase of glycinuria (table 6) was more significant when expressed as a fraction $\left(\mathrm{p}<10^{-3}\right)$ than as $\mu \mathrm{mol} / \mathrm{g}$ creatinine $\left(\mathrm{p}<10^{-2}\right)$.

\section{Discussion}

Not all amino acids were measured in this investigation. Some (taurine, $\beta$-aminoisobutyric acid, tryptophan) were omitted for technical reasons, the elution of the resin being adapted to a screening program. Others were omitted because they are poorly excreted in normal subjects (hydroxyproline, cystathionine, methionine, isoleucine, ornithine, arginine), but these are all separated and can be measured if their concentrations are increased.

A single morning urine sample is normally used for the determination of reference values for aminoaciduria (21), and the amino aciduria is normally related to creatinine excretion. Creatinine concentration was claimed to be relatively constant in the single morning urine sample $(20,21)$. This assumption is certainly true for any one subject, the amino acid excretion showing little variation during several days (table 1). But the variation of muscular weight with age and sex causes the results for different individuals to be more scattered (tables 2 and 3). Moreover the immaturity of renal amino acid transport systems $(22,23)$ may explain the differences observed between the first group of subjects (less than 1 month old) and the others. The use of the sum of predominant amino acids in the excretion pattern as a criterion significantly decreases the variances of results (table 5). The amino acid excretion related to the creatininuria is a useful index for the diagnosis of aminoacidopathies and aminoaciduria, but it is inadequate for the appraisal of small changes in one or several amino acids. Thus the effect of $n$-dipropyl acetate therapy on glycinuria appears more dramatic when expressed as a fraction change. When results are expressed in $\mu \mathrm{mol} / \mathrm{g}$ creatinine (table 6), glycinuria overlaps the limit of two standard deviations in 6 cases only; it stays between $\bar{x}+1 \mathrm{~S}$. D. and $\bar{x}+2$ S. D. in one case; it remains between $\bar{x}$ and $\bar{x}+1$ S. D. in two cases and is even inferior to $\bar{x}$ in one case. When results are expressed as a fraction glycinuria is always over $\bar{x}+1$ S. D. and in 8 cases, overlaps $\bar{x}+2$ S. D. This gives a better statistical significance in a t-test with paired series $p<0.001$ $(t=5.53)$, whereas $p<0.01(t=3.54)$ for the former method.

The method of expression described here makes it possible to study moderate variations in the excretion of only some amino acids; such changes may be spontaneous or due to drug administration. It also removes the need to assay aminoaciduria and creatininuria simultaneously on a total 24 hour urine.

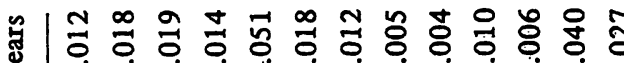

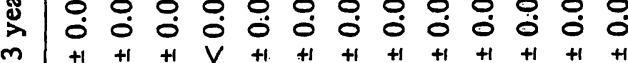

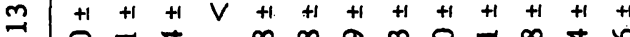

惫

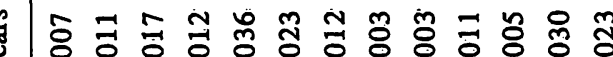

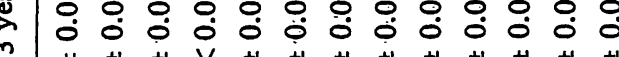

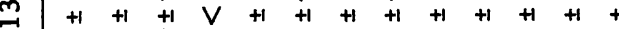

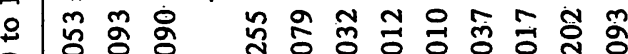

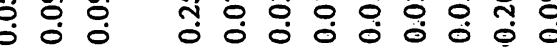

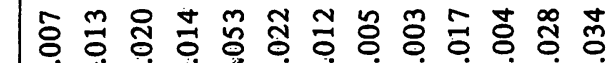
过

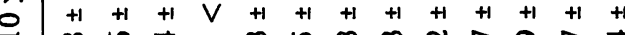

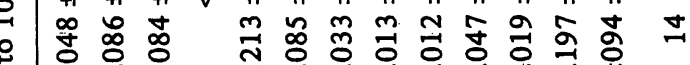

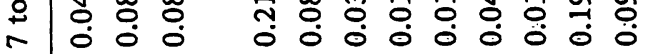

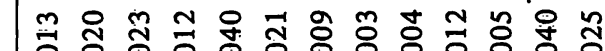

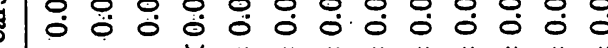

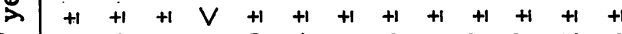

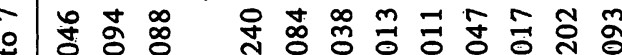
更

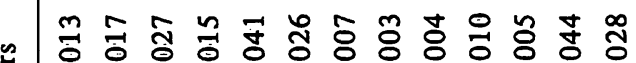

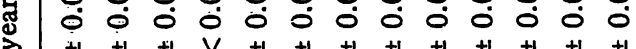
+ $\circ$ ○

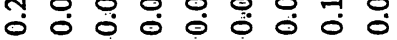

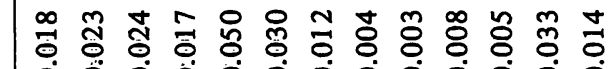

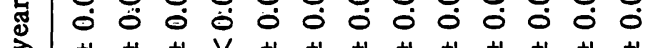

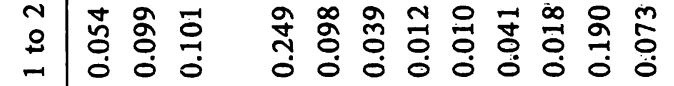

సี సิ

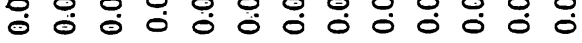

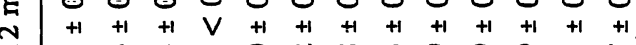

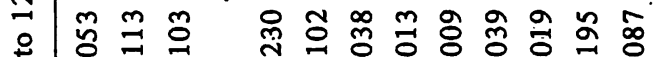

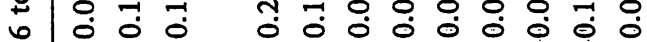

๙ o 0 0 : 0 ö E

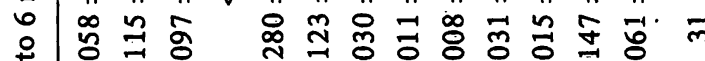

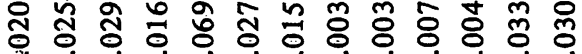

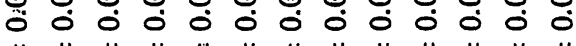


Tab. 5. Comparison of coefficients of variation observed in tables 3 and 4.

CV for giving the results

in $\mu \mathrm{mol} / \mathrm{g}$ creatinine

(\%)

\begin{tabular}{|c|c|c|c|c|}
\hline Threonine & $43.6 \pm 5.0$ & $26.8 \pm 8.8$ & 6.05 & $<0.001$ \\
\hline Serine & $41.0 \pm 6.0$ & $20.0 \pm 4.3$ & 9.62 & $<0.001$ \\
\hline Glutamic acid + glutamine & $44.1 \pm 3.6$ & $28.7 \pm 7.7$ & 5.91 & $<0.001$ \\
\hline Glycine & $43.3 \pm 3.0$ & $20.4 \pm 4.7$ & 11.17 & $<0.001$ \\
\hline Alanine & $41.8 \pm 4.5$ & $27.6 \pm 4.5$ & 5.94 & $<0.001$ \\
\hline $1 / 2$ Cystine & $40.0 \pm 5.3$ & $33.2 \pm 7.4$ & 2.64 & $<0.02$ \\
\hline Valine & $35.6 \pm 6.8$ & $31.0 \pm 6.2$ & 2.65 & $<0.02$ \\
\hline Leucine & $39.2 \pm 6.9$ & $36.1 \pm 6.7$ & 1.30 & NS \\
\hline Tyrosine & $36.9 \pm 5.0$ & $27.3 \pm 6.2$ & 3.18 & $<0.01$ \\
\hline Phenylalanine & $39.1 \pm 4.4$ & $31.6 \pm 6.9$ & 3.36 & $<0.001$ \\
\hline Histidine & $37.8 \pm 6.9$ & $20.6 \pm 4.8$ & 4.98 & $<0.001$ \\
\hline Lysine & $39.8 \pm 4.8$ & $30.6 \pm 6.9$ & 3.58 & $<0.01$ \\
\hline
\end{tabular}

Tab. 6. Effect of $n$-dipropyl acetate therapy on glycinuria: Controls were the same age as the corresponding patients; results are expressed by mean $\pm \mathrm{SD}$.

\begin{tabular}{|c|c|c|c|c|c|c|}
\hline \multirow[t]{2}{*}{ Age } & \multicolumn{2}{|c|}{$\begin{array}{l}\text { Glycine expressed } \\
\text { in } \mu \mathrm{mol} / \mathrm{g} \text { creatinine }\end{array}$} & \multicolumn{2}{|c|}{$\begin{array}{l}\text { as a fraction of the sum of } \\
14 \text { amino acids (see results) }\end{array}$} & \multicolumn{2}{|c|}{$\begin{array}{l}\text { Total aminoaciduria } \\
(\mu \mathrm{mol} / \mathrm{g} \text { creatinine })\end{array}$} \\
\hline & Subjects & Controls & Subjects & Controls & Subjects & Controls \\
\hline 5 years & 905 & $1620 \pm 745$ & 0.570 & $0.240 \pm 0.040$ & 1594 & $5351 \pm 2148$ \\
\hline 3 years & 4630 & $2364 \pm 964$ & 0.420 & $0.245 \pm 0.041$ & 11023 & $7960 \pm 2511$ \\
\hline 6 years & 3750 & $1620 \pm 745$ & 0.590 & $0.240 \pm 0.040$ & 6378 & $5351 \pm 2148$ \\
\hline 9 years & 1364 & $977 \pm 402$ & 0.550 & $0.213 \pm 0.053$ & 2463 & $4713 \pm 2030$ \\
\hline 5 years & 3125 & $1620 \pm 745$ & 0.450 & $0.240 \pm 0.040$ & 6925 & $5351 \pm 2148$ \\
\hline 3 years & 6800 & $2364 \pm 964$ & 0.390 & $0.245 \pm 0.041$ & 17435 & $7960 \pm 2511$ \\
\hline 14 months & 7412 & $2138 \pm 853$ & 0.370 & $0.249 \pm 0.050$ & 20032 & $7574 \pm 2191$ \\
\hline 11 years & 2604 & $1194 \pm 501$ & 0.320 & $0.255 \pm 0.036$ & 8137 & $4609 \pm 1727$ \\
\hline 6 years & 3077 & $1620 \pm 745$ & 0.368 & $0.240 \pm 0.040$ & 8362 & $5351 \pm 2148$ \\
\hline 3 years & 3912 & $2364 \pm 964$ & 0.300 & $0.245 \pm 0.041$ & 13040 & $7960 \pm 2511$ \\
\hline
\end{tabular}

\section{References}

1. Soupart, P. (1962), Amino-acid Pools (Holden, J. T. ed.) Elsevier Publishing Company, 220-262.

2. Armstrong, M., Kerin, P., Yates, K. \& Connelly, J. P. (1964), Pediatrics 29, 975-978.

3. Gaull, E. G., Rassin, K. E. \& Raiha, N. C. R. (1977), J. Pediatr. 90, 507-510.

4. Hemery, A. E. H. \& Burt, D. (1972), Clin. Chim. Acta 39, $361-365$.

5. Thompson, R. C., Gaull, E. G., Horwitz, S. J. \& Schenk, R. K. (1969), Amer. J. Med. 47, 209-219.

6. Passwell, J., Zipperkowsi, L., Katznelison, D., Szeinberg; A., Crispin, M., Pollak, S., Bat-Miriam, M. \& Cohen, B. E. (1973), J. Pediatr. 82, 466-471.

7. Bremer, H. J. \& Przyrembel, H. (1974), Clin. Endocrinol. Metab. 3, 131-143.

8. Lefler, W. H., Wadsworth, J. A. C. \& Sidbury, J. B. (1971), Amer. J. Ophtalmol. 71, 224-230.

9. Perry, T. L., Dixon, G. H. \& Hansen, S. (1965), Nature 206, 895-897.

10. Wiseman, C., Robert, F., Mc. Gregor, Ph. \& Mc. Credie, K. B. (1976), Cancer 38, 219-224.

11. Brown, R. R. (1967), Science 157, 432-434.

12. Kamoun, P., Parvy, P. \& Debray-Ritzen, P. (1977), Nouv. Presse Med. 6, 2162.

13. Jaeken, J., Corbee, L., Casaer, P., Carchon, H., Eggermont, E. \& Eeckels, R. (1977), Lancet $I I, 8038$.

14. Bartlett, K. (1977), Lancet $I, 716$.

15. Kamoun, P. \& Parvy, P. (1978), Helv. Paed. Acta 33, 379-383.

16. Armstrong, M. D. \& Yates, K. K. (1964), Amer. J. Obstet. Gynecol. 88, 381-385. 
17. Bonsnes, R. W. \& Tausski, H. H. (1945), J. Biol. Chem. $158,581-585$.

18. Piez, K. A. \& Morris, L. (1960), Anal. Biochem. 1, 187192.

19. Castets, J. C., Parvy, P., Allard, D. \& Huang, Y. (1978), Ann. Biol. Clin. 36, 143-147.
20. Berry, H. K. (1960), Pediatrics 25, 983-996.

21. Berry, H. K. (1960), Metabolism 9, 363-372.

22. Segal, S. \& Thier, S. (1973), Handbook of Physiology, Section 8, 653-67.6.

23. Brodehl, J., Gellissen, K. \& Jakel, A. (1968), Pediatrics 42, 395-404.
Prof. Dr. P. Kamoun

Laboratoire de Biochimie Génétique Hôpital Necker

F-75730 Paris Cedex 15

France 